\title{
SURVEY OF EQUIPMENT QUALITY CONTROL IN RADIOTHERAPY CENTRES IN CROATIA: FIRST RESULTS*
}

\author{
Slaven JURKOVIĆ ${ }^{1}$, Ana DIKLIĆ ${ }^{1}$, Mladen KASABAŠIĆ ${ }^{2}$, Đeni SMILOVIĆ RADOJČIĆ ${ }^{1}$, \\ Manda ŠVABIĆ ${ }^{1}$, Ana IVKOVIĆ ${ }^{2}$, and Dario FAJ ${ }^{2}$ \\ University Hospital Rijeka, Radiotherapy Department, Rijeka ${ }^{1}$, University Hospital Osijek, Radiotherapy and \\ Oncology Department, Osijek², Croatia \\ Received in April 2011 \\ CrossChecked in May 2011 \\ Accepted July 2011
}

\begin{abstract}
Implementation of advanced radiation therapy techniques in clinical practice can greatly improve tumour control and normal tissue sparing. An important part of this implementation is quality control (QC) of every part of the radiotherapy process, as it helps to detect errors and provides instant remedy. This increases the probability of successful radiation treatment and ensures patient radiation safety. Every radiotherapy quality assurance (QA) programme is based on quality control of radiotherapy equipment. The aim of our survey was to review QC practices in a number of radiotherapy centres in Croatia. As a first step, we defined a set of tests to check different parameters of linear accelerators and simulators in these centres. The tests were defined and performed according to protocols developed at two university hospitals. Test results varied largely between the centres. This calls for harmonisation of QC protocols.
\end{abstract}

KEY WORDS: linear accelerator, mechanical accuracy, quality assurance, radiation accuracy, radiation therapy

Implementation of advanced radiation therapy techniques in clinical practice can greatly improve tumour control and normal tissue sparing. Conformal radiation therapy (CRT) and intensity-modulated radiation therapy (IMRT) make it possible to precisely tailor dose distributions and reduce irradiated volumes. This would not be possible without linear accelerators, which must be very precise, well tuned, and regularly maintained. Quality control (QC) of linear accelerators is the basis of radiation therapy quality assurance programmes (1).

* Partly presented at the $8^{\text {th }}$ Symposium of the Croatian Radiation Protection Association with international participation, Krk, Croatia 13-15 April 2011
The first step in developing a QC programme is to write down QC protocols. According to an earlier study by Švabić et al. (2), written QC protocols are rare in Croatian radiotherapy centres (2). Quality control of equipment is usually left to the conscience of medical physicists.

Within the framework of projects CRO6008 and RER9093 granted by the International Atomic Energy Agency (IAEA) we harmonised the existing QC protocols between the radiation therapy departments at university hospitals of Rijeka and Osijek and developed new ones following international guidelines (3-5). They are publicly available at the website of the Croatian Medical and Biological Engineering Society, 
Medical Physics Division (6) to help other radiotherapy centres/departments in Croatia develop their own protocols.

The next step was to review existing QC practices (7) in different Croatian radiotherapy centres and exchange experiences with them. For that purpose, we defined a set of tests for QC parameters based on the existing QC protocols and tested linear accelerators and simulators in six radiation therapy centres in Croatia. This paper describes the proceedings and test results.

\section{MATERIALS AND METHODS}

The tests were performed in six radiotherapy centres in Croatia (three in Zagreb and one in Split, Osijek, and Rijeka) and included nine linear accelerators and six simulators (Table 1). Test procedures were based on well-established QC protocols at university hospitals of Rijeka and Osijek.

We used regular tools for routine QC, including mechanical distance indicator, multi-purpose precision alignment device Iso-Align (Civco, USA), constancy check device QuickCheck Webline (PTW, Germany) for essential beam parameters, QC3 and FC-2 phantoms, a PIPSPro programme package (Standard Imaging, USA) to check parameters of portal imaging devices (8), X-Omat V (Kodak, USA) radiographic films, DosimetryPro scanner (Vidar, USA), and a
Coherence Physicist WS (Siemens, Germany) for radiation accuracy tests. Some tests were not performed on all machines since some of the accelerators are old and not equipped with multi-leaf collimators or electronic portal imaging devices. Since output in cGy/MU was the only parameter controlled regularly by all centres, we omitted it from our test list, assuming that all output values were correct. However, output was indirectly checked using the PTW QuickCheck Webline device, and measured doses on the central axis (CAX) as well as beam quality were well within tolerance.

Conventional simulators are also an important part of radiotherapy equipment. They are used to simulate geometrical parameters of a particular treatment machine such as gantry, collimator angle, or field size. Several measurements were done on six simulators, some to determine mechanical and some radiation accuracy (Table 2).

\section{RESULTS}

For the purpose of this study, we collected a large number of data on mechanical and dosimetrical parameters of different linear accelerators. First we investigated the mechanical and geometrical parameters, including precision of optical distance indicator (ODI), lasers, crosshair intersection stability with collimator rotation and field sizes.

Table 1 List of tests performed on linear accelerators

\begin{tabular}{llc}
\hline TEST & CRITERION & TOLERANCE \\
\hline optical distance indicator & mechanical accuracy & $2 \mathrm{~mm}$ \\
\hline field size indicators & mechanical accuracy & $2 \mathrm{~mm}$ on each edge \\
\hline $\begin{array}{l}\text { crosshair intersection stability with } \\
\text { collimator rotation }\end{array}$ & mechanical accuracy & radius $1 \mathrm{~mm}$ \\
\hline laser alignment with isocentre & mechanical accuracy & $2 \mathrm{~mm}$ \\
\hline $\begin{array}{l}\text { light/radiation coincidence (symmetric and } \\
\text { asymmetric fields) }\end{array}$ & radiation accuracy & $2 \mathrm{~mm}$ on edges; $1 \mathrm{~mm}$ on \\
\hline collimator rotation & radiation accuracy & central axis \\
\hline gantry rotation & radiation accuracy & radius $2 \mathrm{~mm}$ \\
\hline treatment couch rotation & radiation accuracy & radius $2 \mathrm{~mm}$ \\
\hline $\begin{array}{l}\text { leaf positions with MLC (multi-leaf } \\
\text { collimator) }\end{array}$ & radiation accuracy $2 \mathrm{~mm}$ \\
\hline symmetry/flatness & radiation accuracy & $2 \mathrm{~mm}$ \\
\hline $\begin{array}{l}\text { flat panel parameters } \\
\text { radion }\end{array}$ & radiation accuracy & $\pm 5 \%$ \\
\hline
\end{tabular}


Table 2 List of tests performed on conventional simulators

\begin{tabular}{llc}
\hline TEST & CRITERION & TOLERANCE \\
\hline field size indicator & mechanical accuracy & $2 \mathrm{~mm}$ \\
\hline crosshair intersection stability & mechanical accuracy & $2 \mathrm{~mm}$ \\
\hline laser alignment with isocentre & mechanical accuracy & $2 \mathrm{~mm}$ \\
\hline light/radiation coincidence & radiation accuracy & $2 \mathrm{~mm}$ \\
\hline collimator rotation & radiation accuracy & $2 \mathrm{~mm}$ \\
\hline
\end{tabular}

Figure 1 shows the distribution of mechanical accuracy tests on linear accelerators. Crosshair intersection stability with collimator rotation was the parameter most frequently out of tolerance with $22.2 \%$ above $2 \mathrm{~mm}$. Other values were mainly within tolerance.

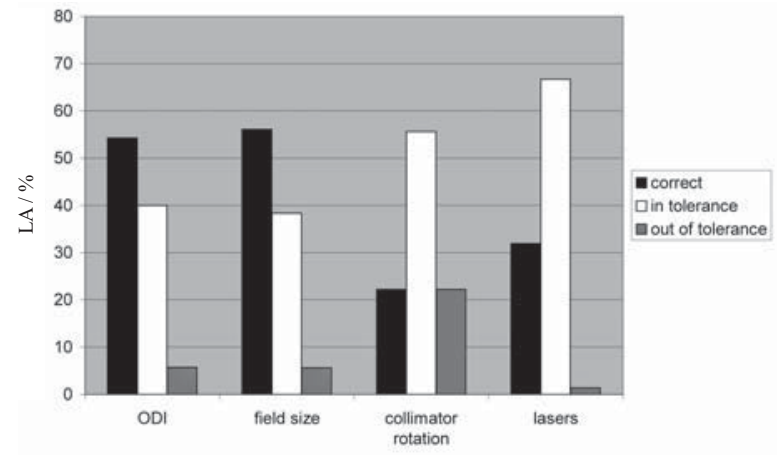

Figure 1 Results of mechanical accuracy tests performed on linear accelerators (LA). As tolerance values differ between diverse tests, we used the term "correct" for differences less than half the tolerance value. For values "within" and "out of tolerance" see Table 1.

The term radiation accuracy includes a large number of beam parameters, but we limited our survey to radiation isocentre dependence on gantry, collimator and table rotation (star shots), coincidence of light and radiation field sizes, and verification of beam quality, CAX dose, flatness, and symmetry. The results showed that rotation of treatment table and gantry were above $2 \mathrm{~mm}$ in over $20 \%$ of the tested linear accelerators (Figure 2a). Moreover, linear accelerators equipped with multi-leaf collimator showed $25 \%$ out-oftolerance values for the width of stripes (6) (Figure $2 b$ ). What raises additional concern is that withintolerance inaccuracies in the range of $1 \mathrm{~mm}$ to $2 \mathrm{~mm}$ were found in $50 \%$ of the linear accelerators.

Figure 3 shows light/radiation coincidence in symmetric and asymmetric fields. Coincidence in symmetric and especially asymmetric fields is an important test due to the frequent use of half-fields in radiotherapy [opposed tangential technique for breast

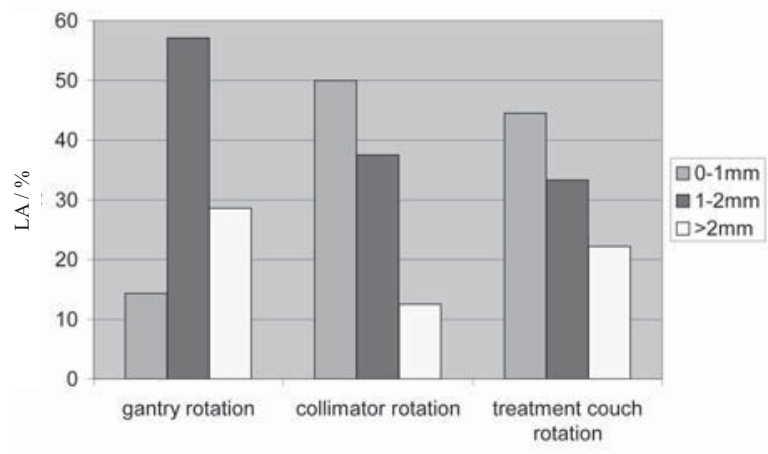

Figure 2a Results of radiation accuracy tests performed on linear accelerators (LA)

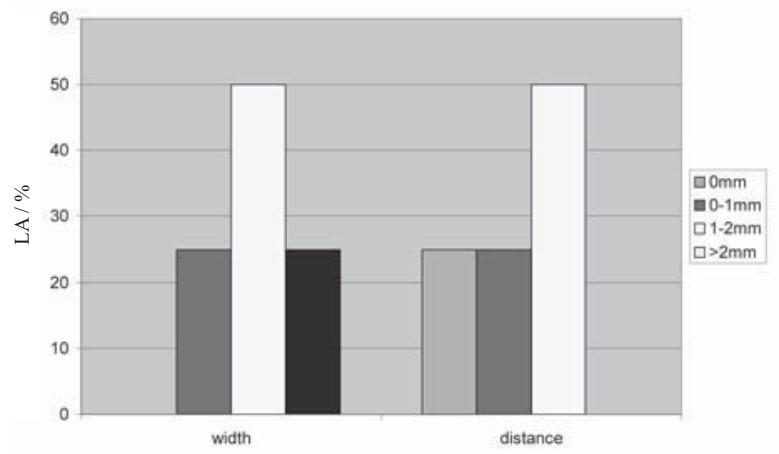

Figure 2b Results of multi-leaf collimator (MLC) parameter tests performed on linear accelerators (LA)

cancer, conformal parotid sparing (ConPas) technique for head and neck cancer]. Overlapping or distinction in asymmetric fields can result in imprecise dose delivery, in low tumour control, and in the damage of organs at risk. Therefore, the $46.2 \%$ of out-oftolerance values on the central axis for asymmetric fields seems quite high. Values for symmetric fields were mostly within tolerance.

Flatness and symmetry were checked on two depths $(0.6 \mathrm{~cm}$ and $5.6 \mathrm{~cm})$ using a PTW QuickCheck Webline system for different photon beams (6 MV, 15 $\mathrm{MV}, 18 \mathrm{MV}$ ) and various electron beams (6 MeV to $21 \mathrm{MeV}$ ). Since the accuracy of this system is lower than of the water phantom system (e.g. IBA, Blue Phantom System), within tolerance ranges are a little higher (Figure 4). Our results showed great stability 


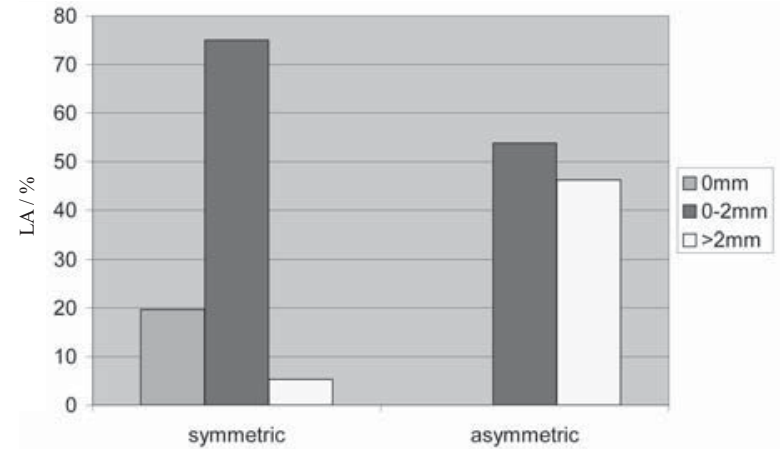

Figure 3 Results of light/radiation coincidence tests performed on linear accelerators (LA)

in symmetry and some out-of-tolerance values for flatness, especially for measurements for photons at the greater depth $(29.4 \%$ showed flatness above $5 \%$ ).

At the time of this study, five of nine linear accelerators were equipped with a system for portal imaging. Unfortunately, only two were suitable for our measurements. The tested parameters were spatial resolution $\mathrm{f}_{50}, \mathrm{f}_{40}, \mathrm{f}_{30}(8,9)$, contrast-to-noise ratio (CNR), noise, field size, and central axis deviation. These parameters were checked using QC3 and FC-2 phantoms. After acquisition, portal images were transferred to PIPSPro system for analysis. Measured values for both flat panels were well within tolerance.

Measurements performed on simulators (Table 2) showed that all values were within tolerance, except for laser alignment, which showed out-of-tolerance values in $8.3 \%$ cases.

The results of this survey were expected since QC of radiotherapy equipment is still neglected by some hospital managements. Having tools for QC is more exception than a rule, and written QC protocols do not exist in more than a half of Croatian radiotherapy departments (2).

\section{CONCLUSION}

Quality assurance of radiotherapy equipment is essential in reducing uncertainties and errors in radiotherapy. Improvement of QA/QC in radiotherapy departments in Croatia is an ongoing process. The past few years however, have seen some improvement, and we hope that a recent purchase of very sophisticated radiotherapy equipment would also raise the awareness of how important QA programmes are. We have

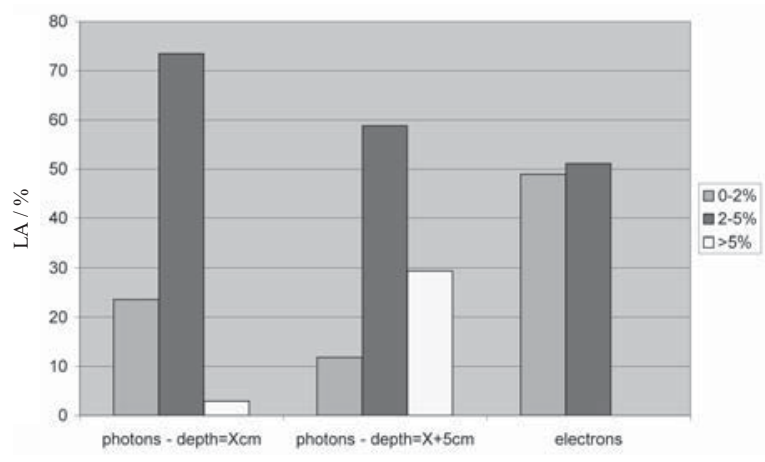

Figure 4 Results of flatness tests performed on linear accelerators $(L A)$

proposed universal QC manuals for different radiotherapy processes that can be used in every radiotherapy department in Croatia. The results presented in this study have been shared with medical physicists working in radiotherapy departments in Croatia. If at least similar QC protocols were used all over Croatia it would be possible to compare results between radiotherapy centres. This is necessary for clinical trials and also for sharing experience between centres (10). The idea of this article is to work toward uniform quality assurance programmes for all radiotherapy centres in Croatia, especially because conditions will be similar in all centres after the installation of newly purchased equipment.

\section{REFERENCES}

1. Meijer GJ, van Kleffens HJ, Mijnheer BJ. Consistency in quality control programmes for electron accelerators in radiotherapy centres. Radiother Oncol 1998;48:103-10.

2. Švabić M, Jurković S, Faj D, Kasabasić M, Smilović Radojčić D, Ivković A. Practises of radiotherapy equipment quality control in radiotherapy centres in Croatia. Coll Antropol 2008;32(Suppl 2):217-9.

3. Klein EE, Hanley J, Bayouth J, Yin FF, Simon W, Dresser S, Serago C, Aguirre F, Ma L, Arjomandy B, Liu C, Sandin C, Holmes T; Task Group 142, American Association of Physicists in Medicine. Quality assurance of medical accelerators. Med Phys 2009;36:4197-212.

4. Nath R, Biggs PJ, Bova FJ, Ling CC, Purdy JA, van de Geijn $\mathrm{J}$, Weinhous MS. AAPM code of practice for radiotherapy accelerators: of AAPM Radiation Therapy Task Group No. 45. Med Phys 1994;21:1093-121.

5. International Atomic Energy Agency (IAEA). Comprehensive audits of radiotherapy practices: a tool for quality improvement. Vienna: IAEA; 2007.

6. Croatian Medical and Biological Engineering Society / Medical Physics Division. Priručnik za kontrolu kvalitete linearnog akceleratora [Linear accelerator quality control handbook, in Croatian] [displayed 25 July 2011]. Available 
at http://medfizika.netai.net/upload/Protokol_ OncorOsijekRijeka.doc

7. Van Dam J, Johansson KA, Bridier A, Sernbo G, Hansson U. EORTC radiotherapy group quality assurance: mechanical checks and beam alignments of megavoltage equipment. Radiother Oncol 1993;29:91-6.
8. Rajapakshe R, Luchka KB, Shalev S. A quality control test for electronic portal imaging devices. Med Phys 1996;23:123744.

9. Droege RT. A practical method to routinely monitor resolution in digital images. Med Phys 1983;10:337-43.

10. Podgorsak EB. Radiation Oncology Physics: A Handbook for Teachers and Students. Vienna: IAEA; 2005. 


\title{
Sažetak
}

\section{UTVRĐIVANJE STANJA KONTROLE KVALITETE OPREME RADIOTERAPIJSKIH CENTARA U HRVATSKOJ: PRVI REZULTATI}

Uvođenje naprednih radioterapijskih tehnika u kliničku praksu ima golem utjecaj na bolju kontrolu tumora i poštedu zdravog tkiva.

Veliku ulogu u tome ima postojanje protokola za kontrolu kvalitete za svaki dio radioterapijskog procesa. Provođenje protokola ključno je za detektiranje pogrešaka i njihovo trenutačno ispravljanje. Time se povećava vjerojatnost za željeni ishod radioterapije i osigurava zaštita pacijenta od neželjenog zračenja. Osnova osiguranja kvalitete u radioterapiji jest kontrola kvalitete samog uređaja. U sklopu projekata financiranih od Međunarodne agencije za atomsku energiju, istraživali smo postojanje protokola za kontrolu kvalitete radioterapijske opreme. Pokazalo se da se testovi kontrole kvalitete provode u svim centrima u Hrvatskoj, no među njima postoje razlike. Također, pisani su protokoli bili rijetko prisutni.

Pregled prakse u kontroli kvalitete i razmjena iskustva pomogli bi u razvoju protokola za kontrolu kvalitete na nacionalnom nivou. Kao prvi korak definirali smo niz testova za provjeru raznih parametara na linearnim akceleratorima i klasičnim simulatorima u radioterapijskim centrima u Hrvatskoj. Testovi su definirani i izvedeni u skladu s protokolima razvijenim u naše dvije bolnice. Sljedeći korak planiran je tijekom ove godine, a odnosi se na verifikaciju sustava za planiranje u kliničkim uvjetima prema protokolu izrađenom u KBC-u Rijeka.

U radu iznosimo pregled provedenih testova, uređaja i računalnih programa za analizu kojima smo se koristili, kao i cjelokupne rezultate.

KLJUČNE RIJEČI: kontrola kvalitete, linearni akcelerator, mehanička točnost, osiguranje kvalitete, radijacijska točnost, terapija zračenjem

\section{CORRESPONDING AUTHOR:}

\author{
Ana Diklić \\ Klinički bolnički centar Rijeka \\ Klinika za radioterapiju i onkologiju \\ Odsjek za radiofiziku i dozimetriju \\ Krešimirova 42, 51000 Rijeka \\ E-mail:abozanic@phy.uniri.hr
}

